TEME, г. XLIII, бр. 1, јануар - март 2019, стр. 225-240

Прегледни рад

Примљено: 29. 3. 2017.

https://doi.org/10.22190/TEME170329002B

Ревидирана верзија: 9. 5. 2017

UDK 347.515 .2

Одобрено за штампу: 30. 5. 2017.

347.513

347.133 .24

\title{
ТАЈНА КАО ПРЕТПОСТАВКА ПОЛИТИЧКЕ МОЋИ
}

\section{Александар Бодрожић}

Академија за националну безбедност, Београд, Србија

bollero@neobee.net

\begin{abstract}
Апстракт
Тајна, као једно од значајних средстава у постизању политичке моћи, подразумева интересантан однос између одређеног податка, знања или информација, чија је садржина позната ограниченом броју лица, која настоје да је као такву сачувају од откривања из одређених личних интереса, ставова или убеђења, са једне стране, и политичке моћи, као једног од најважнијих појмова савремене политике. У вези са изнетим, у раду се настоји пружити одговор на питање да ли је и у коликој мери тајна conditio sine qua поп политичке моћи суверена, односно колико је у демократском друштву заснованом на плуралитету интереса и њиховом међусобном усклађивању оправдано и нужно безбедност демократског поретка заснивати на тајном, јавности недоступном раду извесних државних органа.
\end{abstract}

Кључне речи: тајна, тајност података, политка, политичка моћ, демократско друштво.

\section{SECRET AS AN ASSUMPTION OF POLITICAL POWER}

\begin{abstract}
Secret as one of the important means in achieving political power includes an interesting relationship between specific data, knowledge or information, the content of which is known to a limited number of persons, who are trying to preserve it as such from the disclosure because of certain personal interests, attitudes or beliefs on the one hand, and political power, as one of the most important concepts of modern politics. In connection with the presented, the paper attempts to provide an answer to the question whether and to what extent the secret is a conditio sine qua non of political power of the sovereign, and how justified and necessary it is in a democratic society, which is founded on the plurality of interests and mutual harmonization, to base the security of the democratic order on secret, inaccessible to the public, work of certain state bodies.
\end{abstract}

Key words: $\quad$ secret, confidentiality of data, policies, political power, democratic society. 
„У души државе постоји извесно тајанство

О коме не сме да се говори А чије је дејство божанственије Но што дух и перо могу да опишу."

Вилијем Шекспир

\section{УВОД}

Полазећи од познатог појмовног одређења моћи Томаса Хобса као „средства којима човек тренутно располаже ради добијања неког будућег видљивог добра", може се поставити начелно проблемско питање на чему се све моћ у друштву, приоритетно мислећи на политичку моћ, може заснивати. У контексту поменутог питања, полазну хипотезу овог рада представља став да је тајна једно од значајних средстава у постизању политичке моћи. Ово проистиче из посебног односа између тајне као одређеног податка, знања или информација, чија је садржина позната ограниченом броју лица, која настоје да је као такву сачувају од откривања из одређених личних интереса, ставова или убеђења, са једне стране, и политичке моћи, као једног од најважнијих појмова савремене политике, са друге стране.

У вези са изнетим у раду, настоји се пружити одговор на питање да ли је и у коликој мери тајна conditio sine qua non политичке моћи суверена, односно колико је у демократском друштву заснованом на плуралитету интереса и њиховом међусобном усклађивању, оправдано и нужно безбедност демократског поретка заснивати на тајном, јавности недоступном раду извесних државних органа.

Давање одговора на овако постављено питање јавља се као основни циљ овог рада будући да оно представља демаркациону линију између оних ставова у којима је сваки податак потенцијално могуће прогласити податком од јавног интереса и оних који под паролом „боље је не знати” виде основ сваке сигурности, па и сигурности друштва уопштено посматрано.

У савременом друштву, високо изложеном ризицима од обавештајног наступа страних обавештајних служби, тероризма и организованог криминалитета, све чешће преовлађују популистичке тенденције о потреби подизања степена безбедности друштва, које одобравају дубоко задирање државе, односно суверена у основна људска права човека и грађанина и који разоткривање тајни и сакривање тајни означавају као основни извор и услов сигурности. То посебно погодује држави као носиоцу права на доношење одлуке шта се све у сфери јавног може и мора сматрати тајном и категорисати одређеним степеном тајности. 
Методе које ће у раду бити коришћене спадају у класичне методе друштвених наука, а примењиваће се са циљем да се разумеју и тумаче правни акти којима се регулише појам тајне, тајности и степена поверљивости података.

Као очекивани допринос рада требало би поменути отварање и донекле нуђење одговора на значајно питање у сфери политике, а то је питање у вези са усклађивањем јавног интереса и политичког интереса, њиховим сличностима и разликама и начину на који подаци који се сматрају тајним могу утицати на настанак, одржање и увећање политичке моћи суверена у демократском друштву, као и на питања да ли чување тајне чију садржину представља неко откриће ново знање може утицати на успоравање развоја друштва уопштено посматрано, као и на питање да ли и колико снажан магнетизам у себи поседује тајна за обавештајно деловање у служби званичне политике конкретне државе.

\section{ТАЈНА - ОДРЕБЕЊЕ, САДРЖИНА, ВРСТЕ И ФУНКЦИЈЕ}

У природи сваке тајне, као нечега што је у својој непосредној појавности скривено и неосвешћено, јесте да настоји да буде откривена (Софокле). ${ }^{1}$ У том смислу, поседовање података, информација или знања која други немају, а желели би да их имају - има снажну, готово магнетску привлачност за оне који у њеном откривању и потоњем коришћењу виде свој интерес. Реч је, наиме, о једној посебној врсти интелектуалног изазова за онога који настоји да тајну сазна и продре у њену суштину (садржину), која некада није уопште генерисана неким конкретним интересом, већ искључиво потребом задовољења знатижење - радозналости, која се свакако јавља као један од интелектуалних покретача сваког људског сазнања и изума, као и науке као сврсисходне људске делатности, начелно посматрано. ${ }^{2}$

\footnotetext{
${ }^{1}$ Софоклова политика и одређење тајне почивају на неколико основних постулата, од којих би интересантно било поменути оне који однос човека према тајни изједначавају са његовим односом према самом себи, а процесу откривања тајне придружују прагматичку функцију, јер у њеном одгонетању види елиминисање претње упућене свим појединцима у заједници, а као правог припадника, односно „правог” човека одређује онога који тајну одгонетне. У Софокловој политици тајне може се уочити извесна паралела за савремену политику државе и њених служби безбедности у очувању и откривању тајни (Проле, 2007, стр. 55-59).

${ }^{2}$ Према речима Карла Маркса (Karl Marks), „Свака би наука била излишна када би се појавни облик и суштина ствари непосредно подударали”. Отуда и потиче потреба како појединаца тако и државе, односно њених специјализованих органа и тела, да у информацијама које су доступне и у слободном протоку, пронађу оно нешто што чини њихову суштину, а у онима које нису доступне или су сакривене, проникне у садржину, остварујући на такав начин високо позициони-
} 
Тајна је, као психолошки феномен, обавијена мистичношћу, која је независно од њене непосредне садржине чини интересантном онима који са њом нису упознати. Ирелевантно је при томе да ли је реч о тајни појединца, групе или државе, већ ће тип, односно врста, тајне само утицати на начине, односне средства, која ће бити коришћена приликом њеног откривања.

Одредити тајну спада у једну од сложених интелектуалних делатности будући да се овај феномен може посматрати са становишта великог броја научних дисциплина, те ће природа научне дисциплине која настоји да овај појам дефинише нужно опредељивати и садржину истог, док ће њена непосредна садржина такође утицати на њено појмовно одређење и категоризацију.

У том смислу, као језичка категорија, тајна према Хрватском лексикону представља чињеницу познату ужем кругу особа, за коју постоји оправдан општи или индивидуални интерес да се знање о њој не прошири. ${ }^{3}$

Позната максима француског писца Франсоа ла Рошфукоа (François de La Rochefoucauld) лице коме је поверена тајна означава као господара слободе онога који тајну поверава. ${ }^{4}$

У XVI веку Мартин Лутер (Martin Luther) реч тајна користио је у смислу мистерије и на тај начин користио ју је тумачећи Библију на 37 места (Сибиновић, 2007, стр. 206, фн. 36).

Према одредбама Кривичног законика Републике Србије (КЗ), тајна се може одредити као приватна (лична) или јавна (службена, државна, војна), те постоје инкриминације којима се овакви подаци штите од неовлашћеног откривања. Садржина података којима се пружа кривичноправна заштита одређује и утиче на категоризацију тајни на приватне и јавне, а у контексу поменуте поделе, јавне тајне се односе на податке које су под одређеним условима дужна да чувају државна тела и правна лица са јавним овлашћењима и физичка лица која остварују приступ поменутим квалификованим и неквалификованим подацима, у која се сврставају државна тајна, службена тајна, војна тајна и пословна тајна, док се приватне тајне односе на податке које је једна особа сазнала од друге на основу блиског односа и односа поверења, које се деле на личне и професионалне (Перан, Горета \& Вукошић, 2016, стр. 128-129).

У смислу кривичног дела, неовлашћено откривање тајне из чл. 141, ст. 1 КЗ постоји када адвокат, лекар или друго лище које не-

ран циљ сваке политике - повећање знања и услова за исправно одлучивање и управљање.

${ }_{3}^{3}$ http://www.hrleksikon.info/definicija/tajna.html, приступљено дана 12. 12. 2016.

${ }^{4}$ http://mudremisli.net/tajna-citati/\#laeHTygqXdq6XmEX.99, приступљено дана 5. 11. 2016. 
овлашћено открије тајну коју је сазнало у вршењу службеног позива и предвиђа да ће се такво лице казнити новчаном казном или затвором до једне године. Ради се о кривичном делу које је усмерено ка заштити слобода и права човека и грађанина и које откривање тајне, односно тајних података који су везани за личност учиниоца, тзв. приватну тајну, одређује као објекат коме се пружа кривичноправна заштита (Стојановић, 2009, стр. 390). Будући да је кривично право последње средство у борби друштва против криминалитета, чињеница да оно ипак као кривично дело предвиђа откривање тајне од стране припадника две типичне професије - адвокатске и лекарске - не искључујући при томе неке друге професије, којима припадају лица која су тајну сазнату у вршењу свог позива неовлашћено открила, попут апотекара и свештеника, означава значај који се у нашем друштву придаје праву појединца на личну тајну.

Са друге стране, јавна тајна, односно подаци који представљају службену тајну у смислу поменутог законског акта, чл. 369, ст. 4 подразумевају податке или документе који су законом, другим прописом или одлуком надлежног органа донетим на основу закона проглашени службеном тајном и чије би одавање проузроковало или би могло да проузрокује штетне последище за службу. Кривично дело из чл. 369 КЗ под називом одавање службене тајне систематизовано је у групи кривичних дела против службене дужности и постоји онда када службено лище неовлашћено другом саопшти, преда или на други начин учини доступним податке који представљају службену тајну или које прибавља такве податке у намери да их преда непозваном лииу (Стојановић, 2009, стр. 780-782).

Као категорију јавне тајне, КЗ штити и државну тајну, предвиђајући у чл. 316 кривично дело одавање државне тајне у групи кривичних дела против уставног уређења и безбедности Србије. У оквиру овог кривичног дела дато је одређење појма државне тајне „као података или докумената који су законом, другим прописом или одлуком надлежног органа донесеним на основу закона проглашени државном тајном и чије би одавање проузроковало или могло да проузрокује штетне последице за безбедност, одбрану или за политичке, војне или економске интересе Србије" (Кривични законик Србије, 2014, чл. 316).

Категоризација и одређивање тајни и тајних података, степена и ознака тајности, те начина њиховог чувања ближе је одређена посебним законским прописом (Закон о тајности података, 2009, чл. 2).

Појмовно одређење оних података, ознака тајности, степена тајности, као и лица која им имају право приступити од значаја је за разумевање поштовања тајних података на јавном, државном нивоу.

Како Република Србија има интерес у чувању и поштовању и личних и јавних тајних података, значајно је уочити и истаћи да се 
једнака заштита настоји обезбедити и приватним и јавним подацима, али да друга категорија подлеже детаљнијој обради, дефинисању и заштити, будући да се њиховом повредом, односно дерогацијом правила која одређују начин и услове, те модалитета њиховог коришћења крше права државе и заједнички интерес свих појединаца који државу сачињавају, а који представљају интензивнију повреду и поседују виши степен друштвене опасности. ${ }^{5}$

У овом делу посебна пажња биће посвећена заштити јавних тајни и података, којима се баве специјализоване службе безбедности и остали органи државне управе под одређеним условима, јер је хипотеза постављена у уводном делу рада успоставила потенцијално доказив однос између такве врсте података и потребе њиховог чувања и остваривања и очувања политичке моћи суверена. ${ }^{6}$

\section{ПОЛИТИКА И ПОЛИТИЧКА МОЋ}

Човекова потреба за сигурношћу и осећањем заштићености представљала је један од основа првих заједница, односно груписања људи ради задовољења различитих потреба. Она је у тако формираној групи генерисала потребу „умног вођства” (Симеуновић, 2009, стр. 44) и одабир некога ко ће знати да води групу, некога ко зна пут за постизање већег степена опште користи, као основне идеје заједништва и политике.

Како је, према речима Сигмунда Графа, „политика опхођење са масама и супарницима” (Мијовић, 1993, стр. 564) одабрани представник, вођа, суверен од најранијих времена морао се бавити двема различитим по карактеру и садржини активностима: једном, која се односила на успостављање и одржање власти над сопственим члано-

\footnotetext{
${ }^{5}$ У дугом временском периоду Република Србија, иако декларативно уређена као демократска држава, није имала закон о класификацији и тајности података, тако да је ова област била регулисана у мноштву правних аката различите правне снаге, а који су међусобно били недовољно усклађени (било их је око 400), тако да процедура око стављања ознаке тајности није била транспарентна, што је погодовало злоупотребама. Тежња ка истинској демократизацији друштва, која подразумева ефикасну и доступну контролу институција и државних органа који ограничавају право јавности да зна одређене информације, оличена је у постојању засебног законског прописа којим се свеобухватно регулишу питања тајности података и независних тела као што су Повереник за информације од јавног значаја и Омбудсман.

${ }^{6}$ Појава забране откривања тајне подразумева немогућност да се има апсолутно знање о држави, односно обустава приступа знању, односно располагању знањем, у чијој основи се налази страх од знања, односно могућности да знање постане претња сигурности и безбедности саме државе. О тајни сваке сигурности и идеји да је „боље не знати” (Бојанић, 2007, стр. 9-11).
} 
вима групе, поданицима, и другу, која се односила на сигурност тако издвојене групе у односу на све оне који би је са стране могли угрозити. Реч је о претечама унутрашње и спољне политике власти, односно суверена, која се према Платоновим речима могла одредити као умно и праведно поступање и регулисање међусобних односа у заједници ради постизања складног суживота (Симеуновић, 2009, стр. 45).

Према Аристотелу, политика је највиши и свеобухватни облик друштва (Симеуновић, 2002, стр. 79), а човек је политичко биће. Његова потреба да се удружује, те да таквом заједницом исправно управља довела је до погледа попут Макијавелијевог, који политику види као вештину владања државом, односно стратегију освајања и задржавања власти.

Када се освајање и задржавање власти посматра као политички циљ онога који управља, онда се може говорити и о степену политичке моћи коју он поседује, а која се може одредити као специфична способност остваривања циља који је онај који управља пред себе поставио.

Политичка моћ је заједно са другим врстама моћи, попут економске, војне, религиозне, идеолошке моћи, само једна од подврста укупне друштвене моћи, која се у најширем смислу може дефинисати као способност појединца или групе да сопствене интересе оствари упркос могућем противљењу других лица. Она представља један од централних појмова политике, која има основе различите природе, од којих се најпре помиње економска основа, као могућност располагања друштвеним богатством, искуствена и научна основа, али у контексту поменуте основне хипотезе овог рада и информациона основа, односно моћ која је оличена у поседовању, коришћењу и заштити исправних, корисних и поверљивих података, у право време и на рационалан начин.

Подаци, информације, разумевање и знање опредељују друштвену моћ и утичу најдиректније на политичку сферу, будући да информациона моћ, која у својој основи садржи поседовање знања која други немају, али им је потребно, подразумева способност прикупљања, складиштења и чувања информација које се не налазе у слободном протоку, односно које нису доступне свима (Svete, 2006, стр. 105-106).

Однос зависности између поседовања информација и остваривања политичке моћи уочен је још у време првих заједница, те се прикупљање информација, знања и тајних података, тзв. обавештај-

\footnotetext{
7 Значајно је истаћи да буквални превод израза zoon politicon са старогрчког на латински језик, којим је човек одређен као animal sociale или друштвена животиња, никако не одговора суштини ове Аристотелове мисли, већ је реч о ширем значењу, оном које обухвата све што је живо, дакле, политичко биће. Опширније о грешци приликом интерпретације (Симеуновић, 2009, стр. 47-49).
} 
на делатност, практикује од најстаријих времена, тј. од времена првобитних заједница, па све до данас. Настала је на одређеном степену развоја људског друштва, када је дошло до појаве приватне својине и тајне у међуљудским односима. Тада је човек почео да шпијунира друге људе на начин који никада није примењивао према природи, што ову активност детерминише као друштвену. Основна људска потреба која стоји у позадини сваке обавештајне активности је жеља за постизањем специјалних знања, односно долажење до информација које ће ьиховом имаоиу омогућити одређену корист, предност или неку другу врсту напретка у односу на друге односно откривање тајне.

Право државе, односно суверена, да одређује врсту и облик забране у располагању информацијама, односно знањем, преточено је у обавезу служби безбедности да поменуте информације, односно знања, таје, али и да знање прикупљају, прихватају и тумаче ради њихове потоње директне или индиректне примене од стране суверена. ${ }^{9}$ Поседовање релевантних информација (знања) у правом тренутку омогућава суверену да оствари предност, односно надмоћ $^{10}$, у односу на онога или оно што представља претњу његовој суверености. Суверен на тај начин, таји, односно проглашава, одређене информације, податке и знања као тајне, истовремено прикупљајући, чувајући и користећи знања о свим потенцијалним изворима претње по себе и своју сувереност.

\footnotetext{
${ }^{8}$ Најзначајнији допринос сагледавању обавештајних активности пре н. е. дао је познати кинески генерал и војсковођа Сун Цу. У свом делу Вештина ратовања, написаном у V веку пре н. е., овај кинески генерал указује на неопходност познавања непријатеља и располагања информацијама које омогућују предвиђање. Према њему, исправна предвиђања не долазе од духова и искуства, већ искључиво од шпијуна, које дели на пет врста: месни шпијуни, које употребљава освајач када се користи услугама становништва неког краја; упутаръи шпијуни су они који се бирају међу званичницима непријатеља; преобраћеии шпчјуни су шпијуни непријатеља који су ухваћени и користе се у „наше” сврхе; шпијуни осуђени на пропаст су они који извршавају задатке у циљу обмане дозвољавајући да непријатељ сазна за њих и шпијуни који су преживели опасност задатка, тј. они којима је пошло за руком да се са подацима врате из логора непријатеља. Опширније о анализи обавештајне делатности и целокупног система обавештајног рада Суна Цуа, као и о развоју обавештајних активности у старом веку (Милошевић, 2011, стр. 7-20; Делић, 1997, стр. 111-128).

${ }^{9}$ Intelligere, legere, која је у основи појма Intelligence значи „изабрати, изабрати између”. Intelligence је и интелигенција, и прикупљање, које подразумева анализу нечега, али и само то што се прикупаља. Према речима П. Бојанића, Intelligence је истовремено и служба и циљ (Бојанић, 2007, стр. 13).

${ }^{10}$ Виши степен политичке моћи у односу на непријатеља, заснован на поседовању информационе моћи.
} 
Неспорна потреба онога који управља у држави да се правовремено и исправно информише о стању у својој држави и стању у околним државама са којима остварује добре или лоше односе на политичком нивоу, као и потреба да одређена знања, податке или информације сакрије од других ради заштите, остваривања или повећања сопствене политичке моћи створила је потребу да постоје специјализоване службе и поједини државни органи који ће остварити исказану потребу суверена. ${ }^{11}$

У демократском друштву, које карактериште плуралитет интереса великог броја појединаца који га чине, закон је основни и главни правни акт, односно модалитет државе у уређењу ове специфичне области, ${ }^{12}$ будући да једино он представља средство које у себи поседује квалитет сигурности и демократичности који одговара концепту савремене, либерално оријентисане државе.

Сваки суверен у савременом друштву регулише ову област бројним прописима, чије мноштво, расутост утичу на (не)кохерентност укупног правног система конкретне државе и доводе до непотребне конфузије у регулацији ове значајне области, која у себи, осим интереса државе и појединаца да буду сигурни, обухвата и бројне претње по квалитет демократског режима будући да процес тајења података у себи садржи и опозит једном од савремених начела демократије, а то је транспарентност, односно јавност рада државних органа и специјализованих служби, која мора и може бити изложена критици од стране оних који су суверена изабрали. ${ }^{13}$

Питања модалитета регулисања појмова тајна и тајни подаци, као и услова под којима они могу бити доступни јавности - питање је које досеже најтање и најважније аспекте демократског друштва.

\footnotetext{
${ }^{11}$ Поменуто одређује место и улогу обавештајне службе државе у систему политичке власти у којем обавештајна служба најпре мора бити схваћена као посебан део извршне власти, која своје наменске задатке извршава применом тајних облика и метода, прибављајући при томе суверену поуздане и правовремене информације о чиниоцима и стању у безбедносном окружењу државе. Више о месту обавештајних служби у систему државне власти (Мијалковски, Конатар, 2010, стр. 41-54).

12 Држава се према мишљењу Ј. Бабића јавља као најквалитетнији вид колективног идентитета управо због квалитета одлука које може да донесе у форми закона. Држава није прост збир, агрегат индивидуа, већ као вид колективног идентитета има моћ одлучиваља која је снажнија, јача од моћи појединца. (Бабић, 2007, стр. 50).

${ }^{13}$ Теорија демократије признаје да државни разлог и тајна представљају структуралан проблем за сваку демократију, који се упркос настојањима у вези са транспарентношћу цивилне контроле тајних служби само обнавља у новим облицима. О повезаности политичке моћи и њеној вези са држањем, чувањем, знањем и архивирањем (Лошонц, 2007, стр. 151).
} 
Стога ће у наредном делу рада бити доведени у везу усклађивање јавног интереса и политичког интереса, спорна питања у вези са опасношћу коју у себи садржи чување, односно онемогућавање јавности да се упозна са открићем, односно знањем које би могло да означава предуслов напретка друштва, уопштено посматрано, као и питање о магнетизму који тајна у себи поседује за деловање обавештајних служби.

\section{ТАЈНА И ОСТВАРИВАҢЕ ПОЛИТИЧКЕ МОЋИ У ДЕМОКРАТСКОМ ДРУШТВУ}

Демократска држава, грађанско друштво, политичка слобода, толеранција, сигурност и владавина права термини су који представљају идеал савременог друштва. Човек као друштвено биће, које у основи покреће страх, као механизам реакције на изазове, ризике и претње његовом опстанку, има снажан потенцијал да се ради постизања сигурности удружује и у оквиру групе развија и живи. Највећи број држава јесу присталице демократског уређења државе, али је мали број оних које испуњавају услове које би савремена, либерално оријентисана држава требало да испуњава. ${ }^{14}$

Према речима Фридриха Хајека (Friedrich Hayek), демократију би требало да схватимо „као идеал за који се вреди борити до краја, јер је то наша једина заштита слободе" (Хајек, 2002, стр. 275). Она је предуслов сигурности, слободе, схваћене у најширем смислу, једнакости и благостања.

Демократска држава у којој је суверен изабран одлуком већине подразумева одлучивање које ће у највећој мери изражавати интересе грађана. Носилац права на одлучивање јесте демократски изабран суверен, који ће на основу знања, информација и процена одлучивати шта је у интересу већине. Ту до изражаја долази јавни интеpec, као корист и предност заједнице, који би требало да буде усклађен са интересима појединаца.

Приватни интерес и јавни интерес могу доћи у колизију, у том случају у демократском режиму предност мора бити дата јавном интересу, јер он представља мноштво у односу на интерес појединца, али ће конфликт између ове две категорије довести у питање легитимитет одлучивања суверена и отворити спорно питање чему и у којим случајевима дати предност.

\footnotetext{
${ }^{14}$ Према речима Јургена Хабермаса (Jürgen Habermas), највећи број држава које себе означавају као демократске заправо само „прокламују идеју демократије, о одређеној мери је институционализују, али онда потом фактички спроводе демократију мањине на бази друштвене хијерархија" (Симеуновић, 2009, стр. 133).
} 
Такав је случај и са подацима које суверен проглашава тајним ради сопственог опстанка и повећања моћи и подацима за које је јавност заинтересовна и према стандардима демократске државе има право да се упозна. Р. Ален истиче да је потребно, али истовремено и тешко, дефинисати границу између оправданих и неоправданих тајни и пронаћи прихватљиву црту разграничења између легитимних захтева јавности да зна и потребе чувања одређених података као поверљивих, односно тајних (Alen, 1997, стр. 180). Реч је, наиме, о конфликту који постоји између интереса јавности да зна и интереса одржања и увећања политичке моћи суверена, али и степена безбедности у друштву. Демократија истовремено подразумева информисану јавност, која омогућава грађанима да доносе политичке одлуке и да учествују у политичком животу, али безбедност демократског поретка који се заснива на тајном раду извесних државних служби и апарата (Младеновић, 2007, стр. 171).

Наиме, политика суверена, као конкретна усмеравајућа делатност са становишта целине (Павићевић, 1974, стр. 191), усмерена је како према обезбеђењу сигурности друштва тако и према повећању сопствене политичке моћи. И једно и друго директно је повезано са поседовањем информација и знања која ће суверену омогућити исправно и правовремено деловање усмерено ка остваривању оба постављена циља. Са тим у вези, бројне информације, знања и подаци треба означити тајним како би се одржала и унапредила политичка моћ суверена.

Тајна и тајност података у себи садрже довољан степен важности да би се њихово прибављање и чување могло означити претпоставком политичке моћи. Проблем се јавља у оним случајевима када се тајном прогласе одређени подаци, односно знања која могу бити од значаја за даљи напредак друштва, који је појединачни интерес и сваког појединца. ${ }^{15}$ У таквим случајевима, чињеница да онај који поседује више информација и знање утиче на његово право да у име заједничког, јавног интереса одлучи, чак и у супротности са интересом појединца, односно његовог приватног интереса. Иако је још П. П. Његош говорио „ко на брду ак' имало седи, више види нег’ онај под брдом", мора бити коришћена са максималним опрезом, јер мо-

\footnotetext{
15 Забрана располагањем знањем карактеристична је за службе безбедности које заговарају три налога: „што више знаш - то мање знаш”, „ствари нису онакве какве изгледају да јесу”, „све је у вези, све је повезано”, што у крајњој линији доводи до сакривања знања, односно „слављења” незнања које води стагнацији друштва, која је у супротности са основним идејама демократије, која подразумава отвореност друштва за промене, нова знања и њихове утицаје, тежњу ка знању, које се јавља као претпоставка креативности и даљег напретка (Бојанић, 2007, стр.10-11).
} 
же водити ка стварању тоталитарног система, који је опозит демократији и правној држави.

Сакривање података, информација и знања под плаштом ознаке тајности мора да изражава стварни јавни интерес, који би требало да има карактер претежности у односу на интерес права јавности да зна. Ову танку, демаркациону линију тешко је повући, те је у демократској држави, која осим легитимног интереса суверена да влада, управља, односно остварује и чува своју политичку моћ, неопходно имати како законски оквир који регулише приступ информацијама тако и независна тела која контролишу рад државних органа и специјализованих служби којима је у надлежност стављено одлучивање, чување и употреба тајних података.

У Републици Србији од 2009. године на снази је Закон о тајности података, који је обухватио највећи број релевантних питања из ове области, чиме је отклоњен дугогодишњи недостатак и бројне аномалије у вези са давањем степена тајности подацима који немају квалитет и тежину да се таквима сматрају, уз истовремено одређивање услова, квалитета, надлежности у одлучивању, ознака тајности, приступа, губљење својства тајности и слично.

Када је реч о независним телима у Републици Србији, постоје Заштитник грађана и Повереник за информације од јавног значаја. Заштитник грађана или Омбудсман ${ }^{16}$ представља независан и самосталан државни орган, који је надлежан да штити и унапређује поштовање слобода и права и ужива имунитет, који је претпоставка његове независности и самосталности у раду. Повереник за информације од јавног значаја такође је самосталан државни орган, независан у вршењу своје надлежности, чији је основни задатак да штити остваривање права на слободан приступ информацијама од јавног значаја, чији је рад ближе одређен Законом о слободном приступу информаиијама од јавног значаја и Законом о заштити податка о личности.

Постојање одговарајућих наведених претпоставки за ограничења државног права на одлучивање у сфери тајности података основа је за остваривање основних демократских вредности, правне државе засноване на закону. Ипак, ово специфично право које припада само суверену није без разлога стављено у његове руке, већ је он као легитимно изабрана врховна власт у земљи ипак снабдевен правом и овлашћењима да делује и ради у јавном интересу, у који спада обезбе-

\footnotetext{
${ }^{16}$ Институција омбудсмана је први пут уведена 1809. године у Шведској, са циљем контроле извршне власти, док је у Републици Србији први пут уведена 2005. године Законом о Заштитнику грађана, а његова улога дефинисана је и Уставом Републике Србије.
} 
ђивање безбедности и одлучивање у вези са стратешким потезима државе.

Потреба поседовања тајних информација, података и знања, те њиховог чувања и употребе у циљу остваривања политичке моћи, упоредо са потребом стицања нових информација које могу бити од користи за суверена поверена је посебним специјализованим службама које у складу са законом имају право и обавезу да ове специфичне делатности обављају.

Претпоставка је да ће демократско изабрани органи власти, као што је служба безбедности, као део извршне власти, законито, савесно и у општем интересу обављати послове из делокруга својих надлежности, чему као коректив и ограничење постоје како одговарајући законски оквир тако и постојање независних тела, којима је у надлежност стављена контрола рада поменутих служби.

\section{ЗАКљУЧНА РАЗМАТРАЬА}

Легитимно право сваког суверена - право на доношење политичких одлука - у интересу демократске већине у вези је са бројним одлукама које он у вршењу својих права има. Једно од таквих права свакако је и право у области проглашавања одређених података тајним, као и права у области одлучивања о томе шта се све сматра интересом државе да зна, прикупи и користи, а има карактер тајне.

Све поменуто суверен обавља у циљу одржања већ стечене политичке моћи и повећања своје политичке моћи, што у демократском друштву такође представља право које произлази из корпуса права суверена. Он се у овом себи инхерентном процесу - процесу политичког одлучивања - природно има водити потребом повећања сопствене укупне друштвене моћи, у којој превасходно мислимо на политичку моћ. Она, иако зависна од мноштва компонената, обухвата и сегмент који се односи на специфичне информације, знања и податке, који уколико правовремено и истинито прикупљени за суверена, представљају основ за доношење исправних политичких одлука, усмерених ка повећању политичке моћи.

Изостанак и мањак поменутих информација, података и знања довео би до лоших потеза и политичких одлука, које би могле да угрозе стабилност и снагу суверена у држави. Стога се он према њима неретко односи као према значајном ресурсу своје политичке моћи, означава их као значајне дајући им квалитет и ознаку тајности, а рад својих надлежних органа (специјализованих служби безбедности) усмерава такође ка даљем прибављању, ажурирању и селекцији података, који такође могу бити од значаја за повећање политичке моћи.

Све поменуто неспорно је conditio sine qua поп политичке моћи суверена, јер неадекватно чување тајних података и настојање 
усмерено ка прибављању нових доводи до лоших процена, лошег наступа и недовољно превентивно оријентисаног става према изазовима, ризицима и претњама, што може довести не само до смањења него и до губитка политичке моћи суверена.

Оно што са поменутим недвосмилено мора бити прихваћено јесте демократски механизам контроле оваквих права и интереса суверена, која води заштити мноштва интереса и њиховог усклађивање од стране онога ко је у држави надлежан да се овом заштитом бави. На крају, уз обезбеђење предуслова законитог обављања прерогатива власти, суверен штитећи већи број појединачних интереса, оличен у колективном, јавном интересу, може и мора безбедност целокупног друштва заснивати на тајним подацима и тајном, јавности недоступном раду извесних државних органа. Поменуто карактерише све власти, у свим раздобљима и свим облицима државног уређења, а оно што у крајњој линији мора бити прихваћено јесте да тајна и тајни подаци, како по својој природи тако и по свом карактеру (функцији), представљају предуслов остваривања и обезбеђења политичке моћи и истовремено рањиву тачку сваког суверена, који зарад интереса већине у друштву, дакле, мора истовремено и да их штити и да их прибавља.

\section{ЛИТЕРАТУРА}

Бабић, J. (2007). Слобода, живот и тајна идентитета [Freedom, life and secret identities]. У П. Бојанић (прир.), Политике тајне - тајна, тајна служба, служба државне безбедности [Policies secret - a secret, secret service, the State Security Service] (стр. 39-55). Београд: Народна библиотка Србије, Институт за филозофију и друштвену теорију.

Бојанић, П. (2007). Увод у политике тајне [Introduction to the secret policy]. У П. Бојанић (прир.), Политике тајне - тајна, тајна служба, служба државне безбедности [Policies secret - a secret, secret service, the State Security Service] (стр. 153-171). Београд: Народна библиотка Србије, Институт за филозофију и друштвену теорију.

Делић, М. (1997). Појмовно одређивање обавештајне активности и обавештајне службе [Notional determination of intelligence activities and intelligence services]. Безбедност, 1, 111-128.

Закон о заштити података о личности, Службени гласник РС. Бр. 97(2008), 104(2009) - др. закон, 68(2012) одлука УС и 107(2012).

Закон о слободном приступу информацијам од јавног значаја, Службени гласник РС. Бр. 120(2004), 54(2007), 104(2009) и 36(2010).

Закон о тајности података, Службени гласник РС. Бр. 104(2009).

Кривични законик Србије, Службени гласник РС. Бр. 85(2005), 88(2005) - испр., 107(2005) - испр., 72(2009), 111(2009), 121(2012), 104(2013), 108(2014).

Лошонц, А. (2007). Тајна јавног идиота [Secret of the Public idiot]. У П. Бојанић (прир.), Политике тајне - тајна, тајна служба, служба државне безбедности [Policies secret - a secret, secret service, the State Security Service] (стр. 125-153 ). Београд: Народна библиотка Србије, Институт за филозофију и друштвену теорију. 
Мијалковски, М., Конатар, В., (2010). Необавештајна роварења обавештајаияа [Non intelligence agitation of intelligence officers]. Нови Сад: Прометеј.

Мијовић, М.,(Ур.) (1993). Мислило - књига мисли 1000 мудраџа [Thoughts Thought Paper of 1000 Philosopher]. Београд: Алфа, Сезам.

Милошевић, М., (2011). (Контра)шпијунажа [(Counter) espionage]. Београд: Одбрана.

Младеновић, И., (2007). Демократија, тајне службе и парадокс безбедности [Democracy, Secret Services and security paradox]. У П. Бојанић (прир.), Политике тајне - тајна, тајна служба, служба државне безбедности [Policies secret - a secret, secret service, the State Security Service] (стр. 171-199). Београд: Народна библиотка Србије, Институт за филозофију и друштвену теорију.

Павићевић, Р., (1974). Држава и политика [State and Politics]. Београд: Радничка штампа.

Перан, Б., Горета, М. \& Вукошић, К., (2016). Појам и врсте тајни [Concept and types of secrets]. доступно на www. hrcak.srce.hr/file/220761.

Проле, Д., (2007). Тајне страног - Политике завичајног ума [Secrets of foreign Policies of a native mind].У П. Бојанић (прир.), Политике тајне - тајна, тајна служба, служба државне безбедности [Policies secret - a secret, secret service, the State Security Service] (стр. 55-81). Београд: Народна библиотка Србије, Институт за филозофију и друштвену теорију.

Rajko, A., (1997). Tajni podaci: nužnost i (ili) informativna diskriminacija (Classified information: necessity and (or) an information discrimination). Politička misao, 3, 179-197.

Сибиновић, Ђ., (2007). Место адвокатске тајне у концепту правне државе [Place of a professional confidentiality in the concept of the rule of law]. $\mathrm{У} \Pi$. Бојанић (прир.), Политике тајне - тајна, тајна служба, служба државне безбедности [Policies secret - a secret, secret service, the State Security Service] (стр.199-228). Београд: Народна библиотка Србије, Институт за филозофију и друштвену теорију.

Симеуновић, Д., (2009). Увод у политичку теорију [Introduction to Political Theory]. Београд: Институт за политичке студије.

Svete, U., (2006). Strateški značaj informacijsko - komunikacijske tehnologije u suvremenom međunarodnom okolišu [The strategic importance of information communication technologies in the contemporary international environment]. Polemos, 9, 101-117.

Стојановић, 3., (2009). Коментар Кривичног законика Србије (Сотmеnt of the riminal Code of Serbia). Београд: Службени гласник.

Устав Републике Србије, Службени гласник РС. Бр. 98(2006).

Хајек, Ф., (2002). Право, законодавство и слобода [Law, Legislation and Freedom]. Београд: ЛП Службени гласник CРJ. CID Подгорица.

\section{Извори}

http://www.hrleksikon.info/definicija/tajna.html, приступљено дана 12. 12. 2016. http://www.poverenik.rs/y, u/o-nama/nadleznost.html, приступљено дана 5. 1. 2017. http://www.ombudsman.rs/ приступљено дана 5. 1. 2017. 


\title{
SECRET AS AN ASSUMPTION OF POLITICAL POWER
}

\author{
Aleksandar Bodrožić \\ Academy for national security, Belgrade, Serbia
}

\begin{abstract}
Summary
Democratic state, civil society, political freedom, tolerance, security and rule of law are the terms that represent the ideal of modern society. The legitimate right of every sovereign is to make political decisions in the interest of the democratic majority, which are in connection with his numerous decisions which he has in acting in accordance with his rights. One of these rights is certainly the right to declare certain information as secret, as well as the right in the area of decision-making on what is perceived to be a state interest, to be known, collected and used, and has the character of secret. The aforementioned is the undisputed conditio sine qua non of political power of the sovereign, because improper storage of classified information and efforts directed towards obtaining new ones, lead to erroneous judgments, poor performance and lack of preventive-oriented attitude towards challenges, risks and threats, which can lead not only to reduction, but also to loss of political power of the sovereign. What must be accepted unambiguouly with the aforesaid are democratic control mechanisms of such rights and interests of the sovereign, which lead to protection of multitude of interests and their harmonization, by the one who is in charge of doing so in a country. Finally, while ensuring the precondition of lawful performance of prerogatives of the government, the sovereign - protecting a large number of individual interests, embodied in the collective, public interest - can and must base the safety of the entire society on secret information and clandestine, inaccessible to the public work of certain state bodies.
\end{abstract}

